\title{
Research on the Educational Guidance Mechanism of Campus Loan
}

\author{
Li Junyong \\ Baicheng Normal University, Baicheng, 137000, China \\ 81307602@qq.com
}

Keywords: Campus Loan, Education, Guidance Mechanism

\begin{abstract}
This paper briefly introduces the current situation of campus loans in colleges and universities, expounds the potential risks and contradictions of campus loans, and carries out in-depth research and analysis on the construction of the educational guidance mechanism of campus loans. It is hoped that we can have a clear and comprehensive understanding of the issue of campus loans in colleges and universities, clarify the risk mechanism of campus loans, use targeted educational guidance to achieve effective prevention of campus loans, and minimize the risks and hazards of campus loans, to create a healthy and harmonious space for the development of education for college students.
\end{abstract}

\section{Introduction}

In the development of Internet technology, China's social and economic rapid development. On this basis, the Internet financial lending business flourished. Successively appeared the interesting stage, loves to learn the loan and so on campus loan platform. So far, the scale of Internet consumer credit for college students has reached hundreds of billions. In the development of Internet financial lending business, campus has become an important development place. In the course of the rapid development of campus loans, there are frequent malignant events, resulting in the campus loans bear great pressure and influence of public opinion. In the process of education and teaching, every university must have a clear and comprehensive understanding and grasp of the problem of campus loan, through the optimization and perfection of the guiding mechanism of campus loan education, it can better ensure the healthy, safe growth and development of students. In this paper, research and analysis are carried out.

\section{Current Situation of Campus Loan in Colleges and Universities}

Traditionally, campus loans are loans to college students that include student loans, start-up loans and consumer loans. At present, campus loan, which is widely concerned by all walks of life, refers to the loan behavior of Internet finance industry for college students, which induces college students to overspend and advance consumption by means of loans and zero down payment shopping.

At present, there are two types of loans on campus in colleges and universities. One is the phased shopping platform, which provides advance consumption services for college students by installment payment, such as Credit pay, JD White sliver, etc. The other is the existence of various types of cash lending in online lending platforms. These financial network platforms can earn high interest reports by issuing loans, and the amount of loans is increasing, resulting in college students being trapped in it. There is not enough capacity to repay [1].

Some studies have shown that the most popular forms of campus loan used by college students are Credit pay and JD, and few students use online lending platform to borrow cash directly, which is also related to the reluctance of some students to confess their lending behavior. Some studies have shown that most students' campus loans are mainly for shopping, including cosmetics, clothes, bags, electronic products, etc. A few students' campus loans are mainly aimed at paying off other debts. There are some students on campus loans for the purpose of living expenses and so on. College students in the repayment of campus loans include the following: first, part-time money; 
second, savings in living expenses; third, payment of grants; fourth, to parents to repay money; fifthly, in other loan platforms to borrow money to repay.

\section{The Potential Risk and Contradiction of Campus Loan}

\subsection{Potential Risks of Campus Loans}

Although campus loan can meet the consumption desire of college students to a certain extent and solve the problem of college students' shortage of funds, but because of the lack of strict supervision and supervision of Internet finance, the campus loans that lead to the consumption of campus loans are more harmful to college students [2].

First of all, it induces college students to form wrong consumption concept. Most college students depend on their parents for their financial resources. In the course of the rapid development of our country's social economy, the idea of thrift and diligence has gradually changed, and the ideas of money supremacy and hedonism have come into our country, which makes the concept of mass consumption change greatly. Contemporary college students are not only influenced by the consumption concept of "drinking and drinking today", but also encourage college students to consume ahead of time to a large extent, because college students lack economic independence and ultimately need their parents to bear all kinds of expenses. Most campus loans are easier to borrow, and students can borrow a certain amount only by providing identity information. College students are not deeply involved in the world, under the temptation of consumption ahead of time, it is easy to have transitional consumption habits. In the long run, it has a great impact on the social outlook, outlook on life and values of college students. In addition, College students' excessive consumption will gradually affect the establishment of social credit system [3].

Secondly, the potential risk harms the students' growth. At present, the development of campus loans has not been controlled, there are disorderly development and barbaric development, and the Internet supervision is not in place, which not only has an impact on the normal financial order of our country, but also develops usury by using the way of playing the edge of the ball. At the same time, there is often a phenomenon of campus lending. Students do not have a fixed financial income, so they are very easy to lose their ability to repay under high loans. Loan institutions, faced with problems such as students' overdue repayment of loans, make use of bare slips. Threats and other ways to reduce their own losses. When the students get involved in the high debts of campus network, the whole family will fall into a loan sharking vortex, and they will have to bear the consequences of consumption ahead of time, which will seriously affect the students and their families.

Finally, many college students are impacted and influenced by the tide of bad western thoughts, and the purpose of life is concentrated on consumption and pleasure, too much pursuit of material and money to stimulate, there is serious comparison behavior. Some students are keen on high-grade cosmetics and electronic products, influenced by the wave of campus loans. They are divorced from the real financial affordability of their families and use installments and loans to realize their own consumption desire. Gradually fall into the abyss of campus loans can not extricate themselves. Some girls even spend their money through "bare bars" and end their lives with high loans. The chaos of campus loan will not only lead to the pollution of pure campus, but also breed some bad atmosphere of money and hedonism [4].

\subsection{The Contradiction of Campus Loan}

First, the contradiction between delay satisfaction and instant satisfaction. The reason why campus loan can spread in a short period of time is that it can meet the psychological needs of current college students and attract college students to participate by means of fast auditing and low threshold. Especially in the process of social and economic development, people's consumption concept has changed greatly, and more people are willing to spend tomorrow's money to achieve today's dream. Many college students are difficult to realize the effective control of their own desire in the network consumption. When they face the choice of instant satisfaction and delay satisfaction, 
they prefer instant satisfaction. Campus loan-book identity is convenient and quick to a large extent increases the contradiction between delay satisfaction and instant satisfaction. Different students often have some differences in the way they choose. Some students think that through their own efforts to achieve a better future, this choice can better help college students grow and develop. However, some college students think that the future cannot be predicted, and now they prefer to choose to enjoy themselves in time. As a result of the conflict between these two viewpoints, college students' life choices are affected and they are prone to go into the wrong areas of consumption. Finally, disharmonious consumption and other phenomena appear [5].

Secondly, the contradiction between developmental consumption and excessive consumption. Developmental consumption mainly refers to college students in order to meet their own development needs, from the perspective of enhancing their own ability, using appropriate consumption mode to acquire knowledge and cultivate sentiment, it can be understood that developmental demand belongs to the rational demand. For example, purchase books, participate in textual training and other aspects of consumption, mainly for future development, can be recognized. Some students with relatively difficult family economy can not only promote the development of college students, but also meet the needs of comprehensive quality development of college students under the current social and economic conditions by using reasonable network loans to meet their own development needs. Excessive consumption refers to all kinds of consumption behaviors which are not in accordance with their actual situation, and belong to a wrong consumption mode. Under the influence of global culture, people are more and more influenced by the thought of hedonic consumption. In order to obtain the happiness of consumption, many college students satisfy their own consumption desire through excessive consumption. In this case, it is not only easy to abandon their studies, but also to fall into the abyss of network loan. Although campus loans can provide financial support for college students' life and study, this kind of consumption will also bring negative effects to college students.

Finally, the contradiction between honesty and promise and no breach of contract. Compared with the financial loan, the network loan procedures are convenient, in the examination condition is relatively loose, only needs the applicant to provide the related certificate to be able to obtain the loan. Campus loan is a special marketing activity for college students. If the student fails to repay within the specified time, he will be liable for breach of contract. On the one hand, campus loan can enhance the credit consciousness of contemporary college students and make them realize the necessity of abiding by the agreement; On the other hand, there is a great security risk in campus loans. College students do not have a fixed income, and their sources of living depend more on their parents. Under the influence of the income situation in this respect, college students will face an economic crisis if they are unable to repay their loans in a timely manner. Very easy to have debt problems, but also to bear the responsibility for default [6].

\section{The Construction of Educational Guidance Mechanism of Campus Loan}

\subsection{Launching Special Education and Guidance}

In the process of education and teaching, colleges and universities can regularly carry out related thematic education activities, cultivate the habit of consumption behavior of students' howling, make students have the consciousness of healthy financial management, and realize the effective prevention of all kinds of adverse events. In their daily work, counselors can make use of different forms such as lectures, knowledge competitions and thematic class meetings to make college students have a clear and comprehensive understanding and grasp of the impact of campus loans, and consciously resist all kinds of network lending behavior. At the same time, colleges and universities also need to do a good job of joint education with the family, make use of parental supervision and other roles, to pay enough attention to the economic situation of students.

\subsection{Strengthening College Students' Awareness of Risk Prevention}

On the one hand, credit education for college students is very important in the current social life, 
and personal credit record has an important impact on the future development of individuals. In the future, college students will carry out personal credit record inquiries in the aspects of housing loans and going abroad. In view of the discredit situation of some college students, colleges and universities must pay more attention to the credit education of college students. College students still understand the impact of negative credit records on the future, and clarify the value and role of credit records. College students should not only avoid the influence of credit records, but also maintain good credit records. On the other hand, college students need to establish a correct concept of consumption, campus loans are an advanced consumption mode, although to a certain extent can enhance the consumption and living standards of college students. In a short period of time, it can help college students to finish their studies smoothly, and at the same time, it can improve and strengthen the students' honesty and credit consciousness, so as to solve the problems such as the shortage of college students' funds in a short period of time. However, if college students spend too much, it will be very easy to debt high column situation. Therefore, it needs the joint efforts of society, family and school to help college students to set up a correct consumption concept, weigh the advantages and disadvantages of campus loans, and improve their financial risk prevention level [7].

\subsection{Doing Well the Guidance and Education of the College Students who have already been loaned}

Teachers need to pay full attention to college students and clarify their psychology and life in different ways. For campus loan students, counselors and parents need to communicate and communicate well with students, to understand the repayment ability of college students in detail, and at the same time, to inform students and their parents of the campus loan interest rate, so as to ensure that they can repay the loans within a specified time. Avoid high interest rate and other situations, increase the psychological and mental pressure of college students. In addition, teachers should register and track students in time to understand the consumption of college students and improve the effectiveness of risk prevention on campus loans [8].

\subsection{Attach Importance to Financial Assistance for Students with Financial Difficulties}

Improve the financial aid system, so that the financial difficulties of college students can successfully complete their studies. In the process of subsidizing needy college students, there will be some students with strong self-esteem who are unwilling to confess their family economic situation, and are forced to finish their studies through campus loans under the pressure of living. Therefore, we must pay enough attention to the financial aid work of students with financial difficulties in colleges and universities. Through the way of part-time study and national financial aid, the pressure of students' life and study can be effectively solved, and the correct consumption concept should be formed under the guidance of socialist core values, so as to help college students get out of poverty ideologically. Do not let any of the students in financial difficulties fall into the quagmire of campus loans [9].

\section{Conclusion}

Campus harmony and stability are directly related to the development of social and economic construction in China. The country must pay enough attention to the construction of harmonious campus. The emergence of campus loan has a serious impact on campus harmony and stability. The state must give a targeted education and guidance mechanism to the campus loan problem, and pay more attention to the supervision and management of the network lending environment. Through the work of education and guidance, the consumption concept of college students is promoted, their risk awareness is strengthened, a good foundation is laid for the construction of a harmonious campus, and the healthy development of college students is promoted. 


\section{Acknowledgements}

In this paper, the research was sponsored by the Social Sciences Project of Jilin province during “13th Five-Year Plan” (No. 1492502835141).

\section{References}

[1] LI Zili, HUANG Fen. A Brief Analysis of Measures to Manage Campus Loans in Colleges and Universities [J]. Value Engineering, 2018, 37(12):61-62.

[2] XU Qing. Study on Risk Prevention and Educational Guidance Mechanism of "Campus loan" [J]. The Party Building and Ideological Education in Schools, 2017, (16):62-64.

[3] LU Ruishan, Anchal Gaiba, WANG Aosheng. Investigation and Research on the Present Situation of College Students' Honesty Education-Based on the Perspective of Campus loan [J]. Contemporary Education Research and Teaching Practice, 2018, (9):162-163.

[4] KANG Wei. The Educational Research of Guiding College Students to Set up the Correct Consumption View under the Environment of Campus loan [J]. Read and Write Periodical, 2018, 15(29):2.

[5] ZHANG Yao, BAI Lili. Study on the Positive Effect of Ideological and Political Education in Colleges and Universities on the Development of Campus Loans [J]. Yangtze River Series, 2018, (11):209.

[6] ZENG Xiulin. Analysis on the Current Situation of College Students' Campus Loan and Its Countermeasures [J]. Western China Quality Education, 2018, 4(17):146-147.

[7] ZHAI Jinyun. Study on Risk Prevention and Educational Guidance Mechanism of "Campus loan" Phenomenon [J]. Economic \& Trade, 2018, (14):170.

[8] LIU Beibei. Research on Psychological Health Education of College Students under the Background of Campus Loan [J]. Folder, 2018, (22):170.

[9] ZHANG Jiancun. Study on the Risk Prevention of University Students' Campus Loan Problem from the Perspective of Mental Health Education [J]. Folder, 2018, (22):162. 